
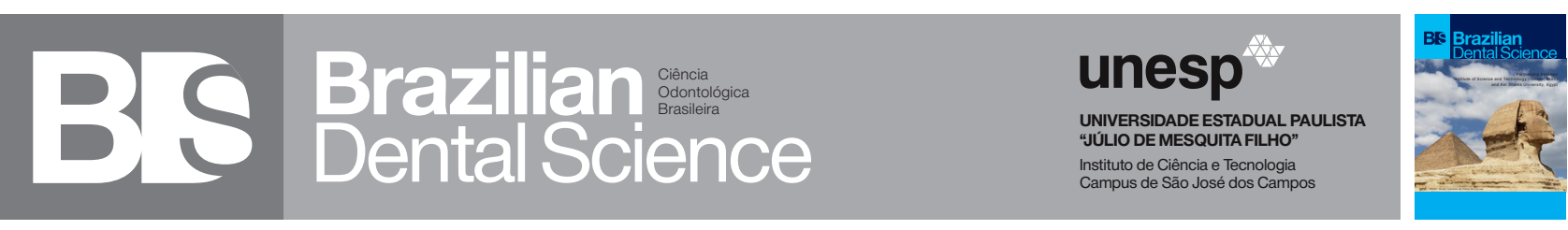

\title{
Oral conditions of pediatric patients with Williams-Beuren syndrome: two case reports
}

\author{
Condição Oral de paciente infantil com Síndrome de Williams-Beuren:dois casos clínicos
}

Flávia Silva PIRES ${ }^{1}$, Viviane Andrade Cancio PAULA ${ }^{1}$, Khawana FAKER ${ }^{1}$, Natália DI LANARO ${ }^{1}$, Raissa Christiane O de CARVALHO ${ }^{1}$, Mônica Almeida TOSTES ${ }^{1}$

1 - Pediatric Dentistry Department - School of Dentistry - Fluminense Federal University - Niterói - RJ - Brazil.

\begin{abstract}
Objective: The objective of this paper was to describe the oral conditions of two children accompanied by their mothers who reported to the Department of Pediatric Dentistry of Fluminense Federal University with Williams-Beuren syndrome (WBS). Case report: The 9-year-old female patient had a family and medical history significant for placental abruption, caesarean section, delayed psychomotor development, learning disabilities, tendency to selfdistract and congenital heart disease. In contrast, the 7-year-old male patient had a normal birth and no gestational intercurrences. Discussion: Clinically, the female presented with mixed dentition, crowding in the maxillary and mandibular arches, prolonged retention of deciduous teeth, anterior and posterior cross-bite and Angle Class I malocclusion, while the male had mixed dentition and retarded psychomotor development. Due to the patients having congenital heart disease, a prophylactic antibiotic regimen was prescribed prior to the dental procedures in both of them. Conclusion: These patients had been followed up for 2 years and this case report underscores the importance of early dental evaluation and counselling for parents of WBS patients.
\end{abstract}

\section{KEYWORDS}

Williams Beuren syndrome; oral manifestations; child.

\section{RESUMO}

Objetivo: O objetivo deste trabalho foi descrever as condições bucais de duas crianças acompanhadas por suas mães que relataram ao Departamento de Odontopediatria da Universidade Federal Fluminense com síndrome de Williams-Beuren (SWB). Caso clínico: Paciente do sexo feminino, 9 anos de idade, tinha história familiar de descolamento prematuro da placenta, cesariana, atraso no desenvolvimento psicomotor, dificuldades de aprendizado, tendência a auto-distribuição e cardiopatia congênita. Em contraste, o paciente de 7 anos de idade teve um parto normal e sem intercorrências gestacionais. Discussão: Clinicamente, a menina apresentava dentição mista, apinhamento nos arcos maxilar e mandibular, retenção prolongada dos dentes decíduos, mordida cruzada anterior e posterior e má oclusão de Classe I de Angle, enquanto o menino apresentava dentição mista e desenvolvimento psicomotor retardado. Devido à doença cardíaca congênita, um regime profilático de antibiótico foi prescrito antes dos procedimentos odontológicos em ambos. Conclusão: Esses pacientes foram acompanhados por dois anos e este relato de caso ressalta a importância da avaliação odontológica precoce e do aconselhamento para pais de pacientes com SWB.

\section{PALAVRAS-CHAVE}

Síndrome de Williams Beuren; manifestações orais; criança. 


\section{INTRODUCTION}

W illiams-Beuren syndrome (WBS) is a rare genetic disease characterised by typical facial features, psychomotor retardation with a specific neurocognitive profile, cardiovascular condition and likely transient hypocalcaemia in infancy [1]. The WBS was first described by Williams in 1961 [2]. In 1962, Beuren [3] thoroughly described the major features that comprise the clinical phenotype of this condition. It affects men and women of any ethnicity. Although it is a rare disease, it is one of the genetic syndromes detected in childhood with an incidence rate of $1: 20,000[3,4]$. The disease is caused by hemizygous microdeletions located on the chromosome $7 q 11.23$ region and can be detected using the molecular cytogenetic technique of fluorescence in situ hybridisation test (FISH) in $90-95 \%$ of patients [7]. Furthermore, a negative result for the ELN gene does not exclude the diagnosis of the syndrome [5-7].

Changes in the elastin genes are primarily responsible for the clinical manifestations, such as supravalvular aortic stenosis, facial changes (elfin facies), soft skin and deep voice [5]. Genetic mutations in this gene make the diagnosis more difficult. [8]. Other clinical manifestations are also observed in WBS, such as hypercalcaemia in childhood, mental retardation, short stature, genitourinary anomalies, and, in some cases, the presence of strabismus and dental anomalies is also common $[5,8]$. Craniofacial manifestations include retrognathic mandible, depressed nasal bridge, macrostomia, prominent lips, enlarged low-set ears, esotropia, hypertelorism (elfin facies), hypodontia, microdontia and small slender roots and delayed mineralisation of the teeth [5]. Due to these anomalies, the dentist contributes significantly to the successful overall management of these patients $[8,9]$. A number of clinical findings have been reported, but few studies evaluating this syndrome consider the oral cavity $[5,6]$. WBS requires complex and individualised treatment planning due to its specific skeletal deformities, dental malformations and lingual muscle dysfunction [6].

The objective of this study was to report on the oral treatment of a 9-year-old female patient and a 7-year-old male patient with WBS and diagnoses of congenital heart disease treated at the School of Dentistry of Fluminense Federal University.

\section{CASE REPORTS}

Two children with WBS were nominated for dental treatment in the ACOLHER/PNE Project at the Paediatric Dentistry School of Fluminense Federal University. Written consent from the parents were obtained for the case reports.

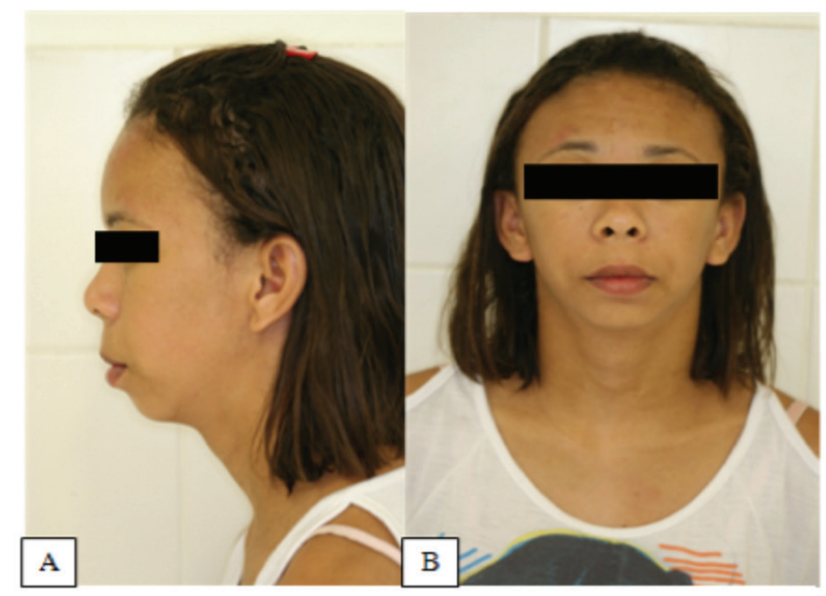

Figure 1 - Facial features Patient \#1. (A, B) A 9-year-old female demonstrates the appearance of Williams-Beuren syndrome. She had a flattened midface, broad forehead, depressed nasal bridge, broad flattened upper lip, long philtrum, thick lips, wide smile, prominent ears and a small chin.

A 9-year-old female patient diagnosed with WBS and referred from the University Hospital Antonio Pedro in the city of NiteroiRJ-Brazil, which provides medical care. This was the first visit to a dentist and the parents of the patient reported a history of both good behaviour and reaction.

\section{Medical history}

The girl's mother reported placental abruption with caesarean section during 
pregnancy. However, the placental abruption had no effects on mother or children. In the first year, the parents observed that Patient \#1 had delayed psychomotor development, learning disabilities and tendency to self-distract. In the first year of life the pediatrician suspected that the child had systemic alteration and referred the mother to a geneticist. From this period the child was diagnosed with the syndrome and was followed up by a multidisciplinary team. Cardiac disease was reported with the presence of congenital heart disease (mitral valve prolapse with mild valvular dysfunction). No continued drug use has been reported. There are no other cases of syndrome or other systemic changes reported by others in the family. The patients had healthy parents and had no family history of the syndrome.

\section{Physical characteristics}

The physical examination of Patient \#1 revealed short stature for her age, normal walking, sloping shoulders and pectus excavatum. Distinctive craniofacial features were a long face, broad forehead, wide cheeks, underdeveloped mandible, pouting lips, widely spaced eyes and "elfin facies" (Figure 1 ). The clinical characteristics were analyzed by a team of multiprofessional doctors. And the responsible brought a medical report to be filed in the dental clinic of the patient.

\section{Dental evaluation}

The intraoral examination showed the patient had mixed dentition, crowding in the maxillary and mandibular arches, anterior and posterior cross-bite, ectopic eruptions (12 and 22), cavitated lesions (84 and 85) and hypoplasia and diffuse opacities (24, 25, 36 and 46) (Figure 2). The patient exhibited poor oral hygiene with biofilm accumulation. The mother related irregular brushing being performed by the child and a diet rich in sucrose. Panoramic radiograph revealed prolonged retention of primary teeth (52, $53,62,63,72,73,74,75,83,84$ and 85). All permanent teeth were present, including the second and third molars (Figure 3 ). The patient had impacted lower and upper canines (Figure 4).

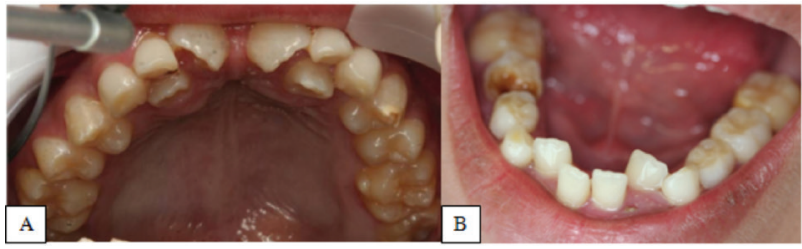

Figure 2 - Oral findings Patient \#1. (A, B) Maxillary and mandibular arches, prolonged retention of deciduous 52 and 62 , presence of rest root element 72 , carious lesion in element 84 and mobility element 85 in exfoliation period.

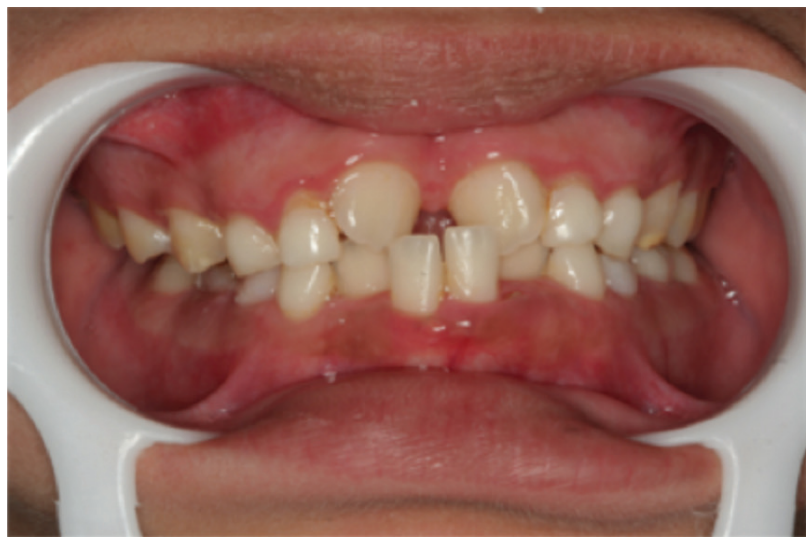

Figure 3 - Occlusion Patient \#1. Angle Class I malocclusion with anterior crossbite.

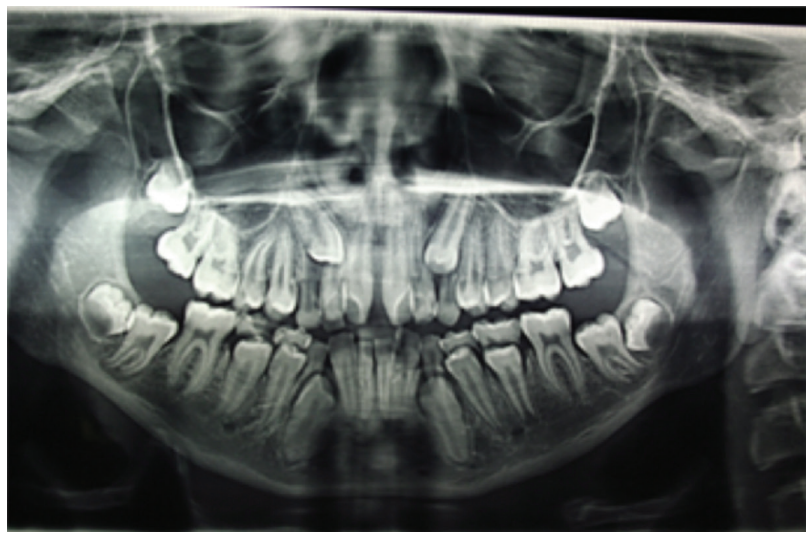

Figure 4 - Panoramic radiograph of Patient \#1 palatinised/ lingualised eruption of permanent lateral incisors. 


\section{Dental treatment}

Considering the age and the clinical and psychological impact of the child's condition, an effective treatment plan was developed. Treatment strategies included extractions of deciduous teeth to improve aesthetics and function. The orthodontic procedures involved expansion of the narrow maxillary arch to obtain a functionally adapted occlusion, creation of room for future alignment and room maintenance in the mandibular arch. Orthodontic appliances were made and cemented: a lingual arch for room maintenance in the mandibular arch and a quad-helix appliance in the upper arch for palatal expansion (Figure 5). After expansion of the maxillary arch, the palatine arch was adapted. Cementation was done using glass ionomer luting. The patient and her parents were educated about the care of the appliance.

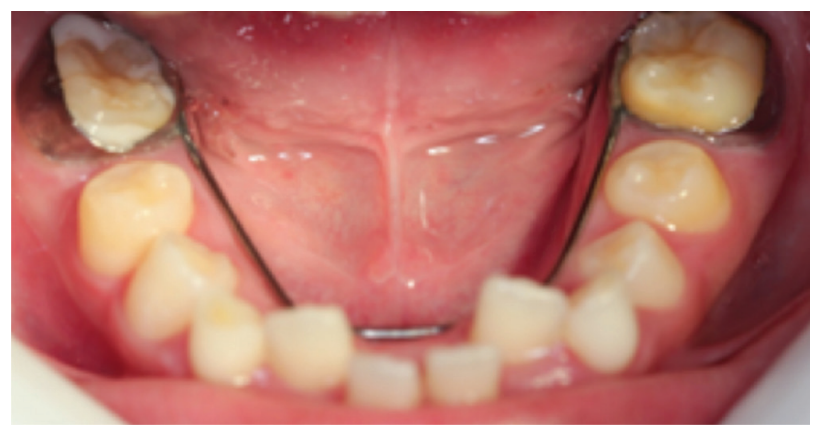

Figure 5 - Mandibular arch Patient \#1. Extractions were carried out of deciduous 52, 62 and residual root of 72 because of the prolonged retention (of the same, leading to the anterior crossbite) with consequent.

Extractions were carried out of deciduous 52 and 62 (using the infiltrative anesthetic technique and palatine) and the residual root of 72 (infiltrative anesthetic technique) because of its prolonged retention (leading to an anterior crossbite) with consequent palatinised/lingualised eruption of permanent lateral incisors (Figure 4). Prophylactic antibiotics were ordered for all invasive procedures due to the presence of a congenital heart defect, following the guidelines of the American Heart Association [10].
The patient was advised to attend regular follow-ups and underwent an orthodontic consultation for malocclusion. Instructions about oral hygiene were given, and the parents were asked to supervise the child's oral hygiene. The patient was advised to maintain oral hygiene and return the appointments scheduled monthly.

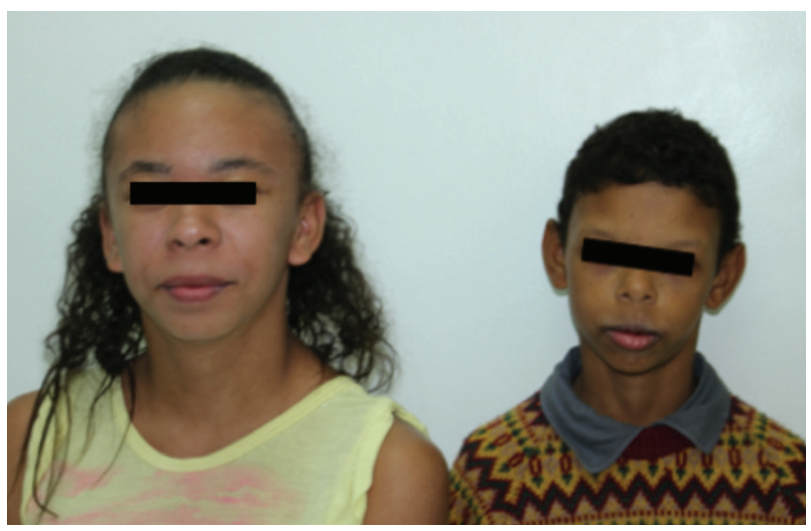

Figure 6 - Patient \#1 and Patient \#2 together. Front view.

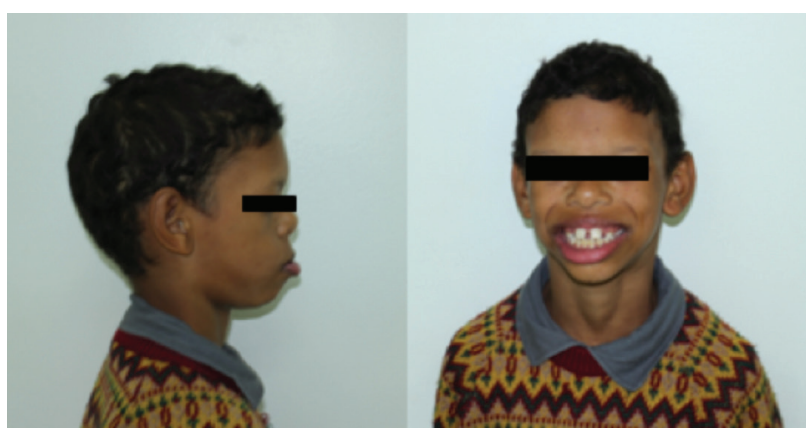

Figure 7 - Facial features Patient \#2.

A 7-year-old male patient diagnosed with WBS arrived for the first time to the dentist with his mother.

\section{Medical history}

The mother's patient reported that both pregnancy and birth were normal. Soon after birth, the doctors who performed the birth were examined and diagnosed the syndrome. From this date the child was followed by a multidisciplinary team. The boy is following up with a neurologist, cardiologist, speech 
therapist, geneticist and physiotherapist. In addition to having congenital heart disease, he presented with retarded psychomotor development. Patient does not report routine use of medications. There are no other cases of syndrome or other systemic changes reported by others in the family.

\section{Physical characteristics}

The physical examination of Patient \#2 showed that the child was short for his age, had a big smile, big ears, bulky lips, small chin and curly hair. As Patient \#1, he had widely spaced eyes and "elfin facies" (Figure 7). This information was provided by a medical report, brought by the responsible in charge. And this report was filed in the patient's file. These medical examinations were performed by a team of multiprofessional team.

\section{Dental evaluation}

The intraoral examination showed the patient had gingivitis, deep palate, mixed dentition and anterior open bite. The patient exhibited poor oral hygiene with biofilm accumulation and supragingival tartar. Panoramic radiograph (Figure 10) revealed that all the permanent teeth were present, but elements 12, 13, 14,15, 22, 23, 24, 25, 33, $34,35,43,44$ and 45 were not yet erupted. Furthermore, he had cavitated carious lesions (16, 36, 46, 55, 74 and 85), hypoplasia and diffuse opacities in all dental elements (Figures 8 and 9).

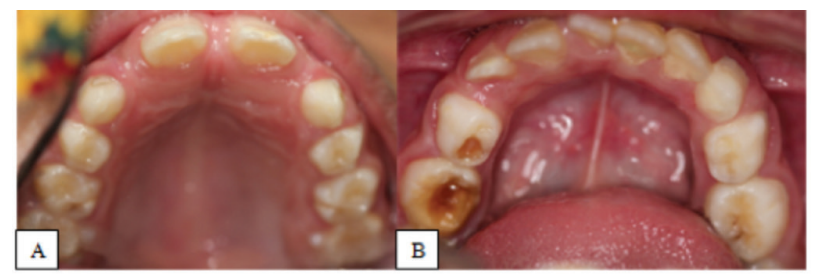

Figure 8 - Oral findings Patient \#2. (A, B) Maxillary and mandibular arches. Biofilm accumulation and lots of carious lesions.

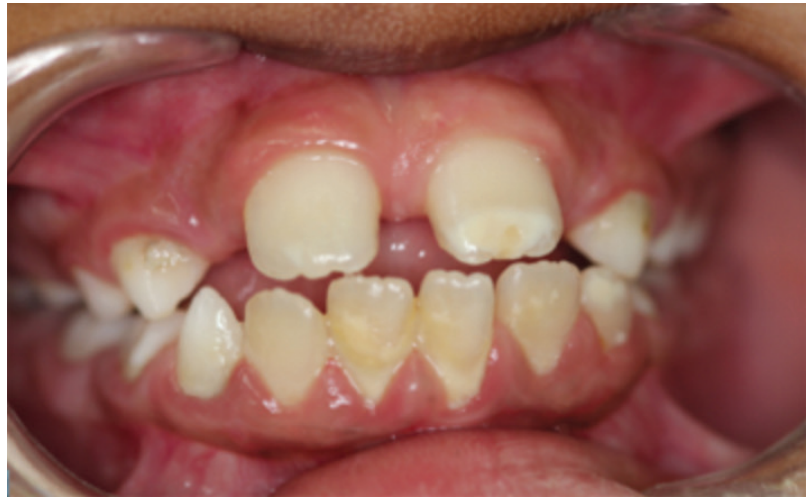

Figure 9 - Occlusion Patient \#2.

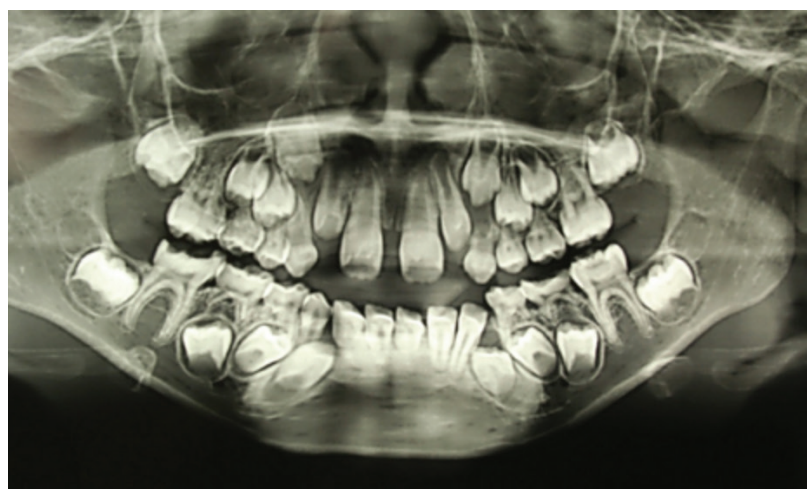

Figure 10 - Panoramic radiograph Patient \#2.

\section{Dental treatment}

It was decided to start treatment with periodontal scraping and prophylactic topical fluoride application. After that, the restoration of deciduous and permanent teeth were realised by accompaniment. The patient was asked to return regularly for accompaniment. 
Table 1 - Most important characteristics in WBS patients.

\begin{tabular}{|c|c|c|c|}
\hline \multicolumn{4}{|c|}{ CHECK LIST - WILLIAMS-BEUREN SYNDROME } \\
\hline \multicolumn{2}{|c|}{ KEYFEATURES } & CASE1 & CASE2 \\
\hline \multirow{2}{*}{$\begin{array}{l}\text { Intercurrences of } \\
\text { birth and childhood }\end{array}$} & $\begin{array}{c}\text { Delay in neuropsychomotor } \\
\text { development }\end{array}$ & $x$ & $x$ \\
\hline & Short stature & $x$ & $x$ \\
\hline \multirow{11}{*}{$\begin{array}{c}\text { Physical } \\
\text { characteristics }\end{array}$} & Curly hair & $x$ & $x$ \\
\hline & Supraorbital prominence & $x$ & \\
\hline & $\begin{array}{l}\text { Depressed nasal bridge } \\
\text { flattened in the middle third } \\
\text { of face }\end{array}$ & $x$ & $x$ \\
\hline & Macrostomia/large mouth & $x$ & $x$ \\
\hline & Big smile & $x$ & $x$ \\
\hline & Bulky lips & $x$ & $x$ \\
\hline & $\begin{array}{l}\text { Wide intercomissural } \\
\text { distance }\end{array}$ & $x$ & $x$ \\
\hline & Dental anomalies & $x$ & $x$ \\
\hline & Small chin & $x$ & $x$ \\
\hline & Big ears & $x$ & $x$ \\
\hline & Prominent muscle mass & $x$ & \\
\hline \multirow{3}{*}{$\begin{array}{l}\text { Cardiovascular } \\
\text { characteristics }\end{array}$} & Supravalvar aortic stenosis & $x$ & \\
\hline & Systemic hypertension & & \\
\hline & Pulmonary artery stenosis & & $x$ \\
\hline $\begin{array}{l}\text { Ophthalmic } \\
\text { characteristics }\end{array}$ & Strabismus & & $x$ \\
\hline Personality & Friendly personality & $x$ & $x$ \\
\hline \multirow{6}{*}{$\begin{array}{l}\text { Neurological } \\
\text { characteristics }\end{array}$} & Mental disability & $x$ & \\
\hline & Infantile spasms & & \\
\hline & Muscle hypotonia & & \\
\hline & $\begin{array}{l}\text { Delay in cognitive } \\
\text { development }\end{array}$ & $x$ & \\
\hline & Children overfriendliness & & \\
\hline & Generalised anxiety & & \\
\hline \multirow{9}{*}{ Oral characteristics } & Class II & & $x$ \\
\hline & Class III & $x$ & \\
\hline & Crossbite & $x$ & \\
\hline & Anterior open bite & & $x$ \\
\hline & Enamel hypoplasia & $x$ & $x$ \\
\hline & Microdontia & & \\
\hline & Incisors in screwdriver & & \\
\hline & Conical incisors & & \\
\hline & $\begin{array}{l}\text { Agenesis (2nd molar and } \\
\text { pre-molar) }\end{array}$ & & \\
\hline
\end{tabular}

Gaps with ' $X$ ' indicate that the patient was a carrier of this characteristic.

\section{DISCUSSION}

WBS is a rare genetic condition, which is inherited or sporadic [2,8]. The presented cases represent a variety of medical and dental problems that are frequently encountered in patients with WBS. The two patients were submitted to oral examination and treatment in the ACOLHER/PNE Project. This study allowed identification of a great diversity of orofacial alterations in the two evaluated patients in comparison to other reported cases.

In Case 1 there was detachment of the placenta during pregnancy; however, caesarean delivery was performed at term. Scientific articles indicate that WBS patients can have healthy parents with no history of familial cases and absence of complications during pregnancy $[5,9,10]$. Overview studies show that there is no relationship between pregnancy complications and the occurrence of WBS.

TheWBSchild canbeinitiallyuncooperative and resistant to treatment, expressing fear and anxiety[5]. Because this, can be show a high risk of decay[11]. These patients can present anterior open bite, atypical swallowing, generalised diastema, hypomineralisation of incisors, enamel hypoplasia and agenesis [5,11,12,13]. This is in contrast to that observed in the present study because Patient \#1 was characteristically cooperative and showed no resistance, had a low rate of decay and the radiographic examination showed all dental elements present. A comprehensive radiographic examination can reveal the presence of dental anomalies, which are typical findings of WBS, and help in the planning of odontology treatment [5]. Patient \#1 was socially active, uninhibited, had a friendly appearance, an extroverted character and was cheerful in nature.

However, this friendly behavior was not observed by Patient \#2. With the Patient\#2 many behavior control techniques (voice control, show-tell-do) were used to make dental care possible. Authors observed that $79 \%$ of WBS children were classified by their parents as outgoing and friendly [14], these data are compatible with Patient \#1. Studies 
demonstrate that WBS patients are social and friendly in nature, having a sociable personality and speaking fluently and intelligibly $[8,13]$.

Malformations of the cardiovascular system are among the most frequently occurring and clinically significant disorders in WBS patients $[3,4,10]$. Cardiac alterations were reported in Patient \#1 and \#2. Due to these cardiac alterations, both patients used antibiotic prophylaxis prior to dental care. Dental management of patients with cardiovascular disease must be coordinated with medical management as prescribed by the physician. Initial medical evaluation (especially of the cardiovascular, renal and nervous systems) is important [3,10]. Among the cardiovascular anomalies, valvular aortic stenosis is the most frequent. Other diseases that affect such individuals include pulmonary artery stenosis coarctation of the aorta with aortic arch hypoplasia, mitral valve prolapse and septal defects. In WBS, localised or diffuse stenosis of the thoracic and abdominal coronal artery and cerebral arteries may also occur.

The facial phenotype found in the clinical examination of the patients corresponds to that described in the literature, whose characteristics were: enlarged forehead, temporal depression, malar hypoplasia, supraorbital oedema, short, upturned nose, depressed nasal bridge, anteverted nostrils, long nasal filter, thick lips, prominent cheeks, large mouth, small chin, clear eyes, starry pattern of iris and frequent smile $[5,8,9]$. Patient \# 1 had some distinctive craniofacial features such as long face, broad forehead, wide cheeks, underdeveloped mandible, pouting lips, widely spaced eyes and "elfin facies", which were similar to Patient \#2.

The enamel hypoplastic defect affects 9.4\% of patients with primary teeth and in $18.5 \%$ with permanent teeth [5,9]. More than half of the WBS patients (59.1\%) were both caries and restoration free, while only 13.6\% presented with clinically active caries. Tongue thrusting was present in $67.7 \%$ of the sample, while more than $50 \%$ of the patients presented with excessive interdental spacing. Patients exhibited a higher than normal prevalence of Class II and III occlusions, open and deep bites and anterior crossbites,[11] which is found in Case 1 (anterior crossbite) and Case 2 (open bite).

They also found $59.1 \%$ of patients free of decay and restoration treatment, and $27.3 \%$ had clinical cavities. However, retreat cavities represented hypoplasia (11.1\%), abnormal morphology of the teeth $(12.5 \%$ - primary dentition; $40.7 \%$ - permanent teeth), enamel hypoplasia $(9.4 \%$ - deciduous dentition; $18.5 \%$ - permanent dentition), atypical swallowing (67.7\%), excessive diastema (50\%), and high prevalence of Class II and III malocclusion (Patient \#1), open bite (Patient \#2) and severe overbite.21 From the same perspective, Conway et al., [15]. identified in the treatment of an 8-year-old male affected by WBS, hypocalcification of deciduous teeth and extensive caries due to poor oral hygiene and agenesis.

There is a higher incidence of gingival and periodontal diseases in WBS patients [5]. This is explained by their poor oral hygiene practices, resulting from the lack of cooperation of the young patients, which is also associated with the malocclusion and agenesis that limits self-cleansing. Furthermore, an important point revealed by the authors of this present study concerns the gene responsible for the formation of elastin, which is missing in WBS patients. This gene is located in chromosome 7, which is missing in this syndrome [5]. Elastin is an essential component of connective tissue. So, the authors here concluded that the high incidence of gingivitis and periodontitis observed in the patients they examined could also be explained by the severe alteration of elastin components of gingival connective fibres, increasing the susceptibility of periodontal tissue to attack by plaque bacteria. In both cases a higher incidence of gingival and periodontal diseases was observed. This fact is explained by the poor oral hygiene practices due to the lack cooperation of the young patients. A strategy was implemented 
to control these oral diseases (gingivitis and caries) through closer consultations (1 month), oral hygiene instruction and supervised brushing.

Preventively, dental evaluation and parental counselling is important in patients with WBS, because the development of caries and endodontic infections may have more serious complications in these individuals, as the high incidence of congenital heart defects increases the risk of subacute bacterial endocarditis $[5,9,10,16,17]$. Preventive dental protocols and dietary counselling must be individually designed and implemented. Given optimal medical, educational, and community support, the quality of life of affected individuals can be improved.

\section{CONCLUSION}

The prognosis for individuals with WBS varies. The majority may be able to master selfhelp skills, complete academic or vocational school and live independently. Apart from this, there are numerous associations for individuals with WBS, which provide resources, support and the latest medical information about the syndrome for all concerned (patients, careers/ families and medical professionals). As a part of this support, odontology treatment can help to provide a better quality of life for these patients.

\section{REFERENCES}

1. De Rubens Figueroa J, Marhx A, López Terrazas J, Palacios Macedo A. Supravalvular aortic stenosis associated to infectious endocarditis and cerebral vascular disease in a patient with Williams-Beuren Syndrome. Arch Cardiol Mex. 2015; 85:292-95.

2. Williams JC, Barratt-Boyes BG, Lowe JB. Supravalvular aortic stenosis. Circulation. 1961;24:1311-18.
3. Beuren AJ, Apitz J, Harmjanz D. Supravalvular aortic stenosis in association with mental retardation and a certain facial appearance. Circulation. 1962;26:1235-40.

4. American Academy of Pediatrics. Health care supervision for children with Williams syndrome. Committee on Genetics. Pediatrics. 2001;107:1192-1204.

5. Torres CP, Valadares G, Martins MI, Borsatto MC, Díaz-Serrano KV, de Queiroz AM. Oral findings and dental treatment in a child with Williams-Beuren Syndrome. Braz Dent J. 2015;26:312-316.

6. Vieira GM, Franco EJ, da Rocha DF, de Oliveira LA, Amorim RF. Alternative treatment for open bite Class III malocclusion in a child with Williams-Beuren syndrome. Dental Press J Orthod. 2015; 20:97-107.

7. Morris CA, Thomas IT, Greenberg E. Williams syndrome: autosomal dominant inheritance. Am J Med Genet 1993; 47:478-481.

8. Carrasco X, Cartollo S, Aravena T, Rothhammer P, Aboitiz F. Williams Syndrome: pediatric and cognitive development. Pediatr Neurol 2005; 323:166-172.

9. Al-Saleem A, Al-Jobair A. Facial and dental manifestations of Williams Syndrome: case report. J Pak Dent Assoc. 2010;19: 48-53.

10. Moskovitz M, Brener D, Faibis S, Peretz B. Medical considerations in dental treatment of children with Williams syndrome. Oral Surg Oral Med Oral Pathol Oral Radiol Endod 2005; 99:573-580.

11. Hertzberg J, Nakisbendi L, Needleman HL, Pober B. Williams syndrome: oral presentation of 45 cases. Pediatr Dent 1994; 16:262-267.

12. Wong D, Ramachandra SS, Singh AK. Dental management of patient with Williams Syndrome - A case report. Contemp Clin Dent 2015; 6:418-420.

13. Udwin 0, Yule W. Expressive language of children with Williams syndrome. Am J Med Genet 1990; 37:108-114.

14. Gosch A, Stading G, Pankau R. Linguistic abilities in children with Williams-Beuren syndrome. Am J Med Genet 1994; 52:291-296.

15. Conway JR, Noonan J, Marion, RW, Steeg CN. Myocardial infarction leading to sudden death in the Williams syndrome: report of three cases. J Pediatr 1990; 117:593-595.

16. Zalzstein E, Moes CA, Musewe NN, Freedom RM. Spectrum of cardiovascular anomalies in Williams-Beuren syndrome. Pediatr Cardiol 1991; 12:219-223.

17. Kawai M, Nishikawa T, Tanaka M, Ando A, Kasajima T, Higa T, et al. An autopsied case of Williams syndrome complicated by moyamoya disease. Acta Paediatr Jpn 1993; 35:63-67.

\section{Dra. Viviane Cancio}

\section{(Corresponding address)}

Universidade Federal Fluminense/Faculdade de Odontologia - Rua Mário Santos Braga, $\mathrm{n}^{\circ} 30$ - Campus Valonguinho, Niterói, RJ, Brazil CEP 24040-110 - Phone: +55 2126299829.

Date submitted: 2018 May 05

E-mail: vicancio@ig.com.br
Accept submission: 2019 Jan 29 